\title{
リスク管理の基本概念と様々な方法論 Concepts of Risks and Different Approaches toward Risk Management
}

\author{
宮本定明 \\ Sadaaki Miyamoto \\ 筑波大学 大学院システム情報工学研究科 \\ Faculty of Systems and Information Engineering \\ University of Tsukuba \\ e-mail: miyamoto@risk.tsukuba.ac.jp
}

\begin{abstract}
The basic concepts of risks and different approaches to risk management are overviewed. It is shown that the basic concepts of risks include both positive and negative meaning with uncertainty, and academic literature defines risks to be measures of uncertainty and the scale of hazards or utility. Hence risks have quantitative measures for the most cases. Decision making is always with risks and there are several different approaches to decision making with risks, some of which are overviewed herein. The issues of risk cognition, risk communication, and nonstandard methods of risk analysis such as fuzzy sets and modal logic are also discussed. The concepts of inverse problems and risk literacy are emphasized.
\end{abstract}

Key words: risk management, risk communication, inverse problem, fuzzy set, modal logic.

\section{1. はじめに}

最近, 社会の安全・安心確保が政府の重点施策となり, それとともに, リスクという言葉が, 専門分野, マス・メディア, インターネットなどで益々盛んに使われるようになってきている. しかしながら，リスクという言葉自体，その定義，概念，受取り方には，多様性とともに本質的 な問題点がある. 本稿では, リスク管理を巡る様々な概念と方法論を概観したい.

\section{2. リスクの概念}

リスクという用語は多くの分野でいまや使用され，様々な意味が与えられるようになってきた. Ansell and Wharton (1992) では, リスク概念は本質的に分野横断的であるため，基本的な概念 についても分野による違いがみられることが明らかにされている. しかしながらあらゆる分野に おいて, リスクとは根本的には避けるべきものではなく, むしろ積極的にとっていく (take risk) ものであることが明言されている.このことを「人間存在にとってリスクは不可避のものであり, リスクをとることのない人間や組織や社会は長く存在できない」と述べている. また，別の表現 
として「リスクのないときが最大のリスク」とも述べられており, 我々が常にリスクを意識しな がら, 意思決定を行い, リスクをとっていくことの必要性が述べられている (Wharton (1992)).

常識的には, リスク回避 (risk avoidance) が基本的立場と考えられるかも知れないが，ここには リスクの定義に関わる多様性と相反性の問題がある. リスクという言葉自体が, 有利と不利とい う相異なる 2 つの意味をもつていることおよび，不確実性が含まれているということが前掲書に は述べられている．また，専門的立場から定義されるリスクは，有利・不利の両方の意味をもつ 事象の不確実性とその規模の測度，とされることが多いが，分野により有利性が強調される場合 と，不利・危険という意味が強調される場合の両方がある．さらに，必ずしも定量的とは限らな いリスクの定義も一般的には認められている.

上に述べたように,「リスク」というときは不確実性があることを前提にしているので, 既に生 じた事象については「リスクが生じた」とは言わない。また，あらゆる事象には何らかのリスク が含まれているといって過言ではないので,「リスクを増大させる」あるいは「リスクを減少させ る」という言い方はあっても, 「リスクをなくす」という言い方は正確でないか, あるいは問題点 が含まれていることが多い.

次節では，リスクは定性的あるいは定量的どちらの立場で管理すべきなのであろうか，という ことをまず問題にしてみたい.

\section{3. リスクの定量化}

多くの専門書ではリスクを定量的に解析することが前提となっている (Ansell and Wharton (1992), Bedford and Cooke (2001), Kammen and Hassenzahl (1999))。この立場を専門外の一般的読者に まで拡げて，啓蒙を試みているのが中谷内 (2006) であり，基本的に主張されているのは，リスク は定量的に把握すべきであり，あるなしの 2 元論で論じるべきではない，ということである．ま た同時に, リスクのモノサシ (基準尺度) との比較により, 各人がリスクを定量化することが提案 されている.

あるなしの 2 元論がリスクゼロの幻想を生むことは, 専門家ならずとも常識であり, リスクを 限りなくゼロに近づけようとすると, 社会的に過大なコストがかかりがちであることも容易に推 察される.

また, 先に, リスクの専門的定義として, 事象 (たとえば事故)の不確実性および規模の尺度, と述べた. 不確実性の尺度として最も標準的なのは確率であり, 上記リスクのモノサシも確率的 考察から生じたものである. 一方, 事故の大きさについては, 最も単純な尺度は被った損失の費 用であろう。

リスクを肯定的に捉える最も典型的な例は，投資・金融であり，そこでは，リスクをとること なしに利益を得ることは不可能である，この場合の尺度は，やはり確率であり，費用である，従つ て, リスクの定量化には, まず確率と費用について考察するべきであり, 多くの研究もこれに従つ ている. また, 環境リスク学では, 確率を平均損失余命に置き換え, 費用の概念と合わせて考察 している(中西 (2004)).

しかしながらリスクの定量化の方法は, 確率論だけに限られるものではない. 後に非確率論的 
観点による不確実性定量化の方法について述べよう.

また，定性的立場からリスクを考察することも不可能ではない．むしろ定性的考察と定量的考 察を組み合わせることによって新たな研究の発展も期待できる. 定性的であり情報科学的方法論 である自動推論の方法はリスク管理や意思決定に利用されることは比較的少ないが, 既存の方法 論と組み合わせて応用していくことが望ましい. リスクは不確実性を論じるものであるため, 不 確実性の論理である様相論理は, 興味ある方法論の一つである. これについても後に述べよう.

\section{1 リスク・不確実性・セキュリティ}

このようにリスクには様々な定義があり，不確実性を伴う事象であるが，risk と uncertainty 厳密に分ける議論もある. Knight (2006) は, risk は計量可能なものを指し, uncertainty は量的 でなく，質的にのみ論じられるものであると定義した．この定義は必ずしも一般的とは限らない が, Knight の立場からすると, リスクは定量的であることがその定義に含まれていることになる.

また, リスクに深い関連をもち, 最近益々重要視されている概念はセキュリティである. セキュ リティという用語は, リスクと違って，セキュリティが保持されているか否かの 2 值判断を要求 するものであり, 定量的判断は乏しい. リスクとの関連では, セキュリティ・リスクというよう に言及され，セキュリティが破れる確率・可能性について定量化が試みられる．なお，セキュリ ティとリスクとの関係について詳細に考察している例として, 甘利 (2004) があり, そこではセ キュリティ概念を中心とした議論が展開されている.

\section{4. リスクと意思決定}

意思決定 (decision making あるいは decision) は, 日常的行動であるが, リスクなしに意思決定 を行うことはない，言い換えれば，意思決定とは，つねに不確実な条件下で行われる行動である といえる．意思決定は，一般に決して合理的なものではなく，認知プロセスを重視しなければな らないというのが最近の考え方であるが(山岸 (1999)), その議論は省略し, まず, 古典的な最適 化による意思決定について考察しよう.このため，簡単な投資の例をとる.

いま，一定の資金を A , B 2 つの銘柄のどちらかに投資したいとする. 過去の経歴をみると，そ れぞれ， $m_{A}, m_{B}\left(m_{A}>m_{B}\right)$ の利益が得られるとする.これだけであると， $A$ に投資すべき， と なるが，分散 $V_{A}, V_{B}$ を考慮することが本質的である. $m_{A}-m_{B}$ がある程度小さく，それに比べ て $V_{A}$ が $V_{B}$ よりもかなり大きいならば， $A$ に投資するのは危険で， $B$ に投資すべきなのはいう までもない。 よく知られたポートフォリオ理論 (たとえば, 刈屋 (1990), 今野 (1995), 甲斐 (2002) などを参照) は複数の銘柄に対し, それらの平均利益と分散とを勘案して, 最適な投資方法を決定 するものである. 上記の例は, 投資に際して, 平均值と分散の両方が情報として与えられなけれ ば，投資の際の情報としては不完全であることを意味している.

金融分野におけるリスク概念の拡大の例として, 国際決済銀行 (BIS) は, 銀行の経営が健全か どうかを示す「自己資本比率」の算定方法の変更を挙げよう(鎌倉 $(2003)$ ).

以前には，貸し倒れなどから発生する信用リスクに，短期取引による保有株等の損失リスクを 意味する市場リスクを合せたものを, 総計のリスクとして, その比率を自己資本比率としていた が，現在は，第 3 のリスクとして「オペレーショナルリスク」すなわちコンピュータ障害や事務 
的ミス, さらにはテロなども視野に入れた損失の期待值も総リスクに含めるようになった. 銀行 には, オペレーショナルリスクの原因を洗い出し, 定量化することが求められている.

また，上記の議論にみられるように，リスクという用語が，前者ではリスクをとつて利益を得 る意味で用いられ, 後者では, 避けるべき危険性の定量化, という消極的な意味で用いられてい ることに注意しよう.このように，同一分野においてもリスクは両義的である.

\section{5. リスク認知について}

最近, 多くのリスク認知研究が発表されている (中谷内 (2006), 岡本 (1992)). リスク認知の研究 は, Kahneman, Tversky によるプロスペクト理論 (Kahneman and Tversky (1979))や Slovicによ るリスク認知の基本因子 (Slovic (1987))などの古典的研究 (Kahneman et al. (1982) も参照)からは じまり, 最近では, リスクコミュニケーション (Kammen and Hassenzahl (1999), 中谷内 (2006)) などと関連して多くの成果を挙げてきた.

ここでは, リスクの定量化にかかわる 2 種類の問題を挙げよう.

\section{1 プロスペクト理論の一側面}

プロスペクト理論については，多くの解説と研究があるが，ここでは，一側面に限って述べよう. ある行動から生起する結果を $x_{1}, x_{2}, \ldots, x_{n}$ とし, それらが確率 $p_{1}, p_{2}, \ldots, p_{n}\left(p_{1}+\cdots+p_{n}=1\right)$ で 生起すると仮定する. $\left(x_{1}, p_{1} ; \cdots ; x_{n}, p_{n}\right)$ のように結果と確率を組み合わせたものをプロスペクト と呼ぶことにする. 以下では, 簡単のため $n=2$ としょう.

期待効用関数にもとづく通常の意思決定理論では,

$$
U\left(x_{1}, p_{1} ; x_{2}, p_{2}\right)=p_{1} u\left(x_{1}\right)+p_{2} u\left(x_{2}\right)
$$

の最大化を論じる.ここで, $u\left(x_{i}\right)$ は各結果についての効用関数であり, その測定方法は多くの 研究で論じられているが, ここでは述べない.

Kahneman, Tversky は期待効用関数が適切でない様々な例を示した後, 次のモデルを提案して いる.

$$
V\left(x_{1}, p_{1} ; x_{2}, p_{2}\right)=\pi\left(p_{1}\right) v\left(x_{1}\right)+\pi\left(p_{2}\right) v\left(x_{2}\right) .
$$

ここで, $\pi(p)$ は確率 $p$ を重みに変換する非線形関数であり, $v(x)$ は価値関数 (value function) と 呼ばれ, 効用関数と区別されている.

価值関数の議論は省略し, 重み関数 $\pi(p)$ について考察しょう. 重み関数は, 確率が意思決定に 影響する重みを表す. $\pi(0)=0$ かつ $\pi(1)=1$ であるが, 多くの認知実験によって, $\pi(p)$ は $p$ が小 さい $(0<p \ll 1)$ とき, 過大に評価され $(\pi(p)>p), p$ が 1 に近いとき $(0<1-p \ll 1)$ 過小に評価 される $(\pi(p)<p)$ ことが知られている. よって, $p$ が 0 あるいは 1 に近いとき, $\pi(p)$ は急激に変 化し, 測定が難しい. リスクの問題は, $p$ あるいは $1-p$ が微小な場合を対象とするため, このよ うに, 意思決定に関わる確率の振舞は不確実かつ敏感になる.このことがリスク解析を難しくし ていることがわかる. 


\section{2 ベイズの定理と認知バイアス}

ベイズ統計学では，事前確率を用いるが，リスク事象に関する認知・判断においては事前確率 が無視されることが多い. よく議論される例を挙げよう. 以下の例は Anderson (1985) によるも のであるが，仮想的であることに注意する，ある人が，医学上の検査を受け，＋の結果が出たと する. + はある種のガンが存在することを意味し，この検査は $95 \%$ 正確，つまりこのガンがある ときに+となる確率は $95 \%$ であるとする.これだけの情報が与えられた場合, 誰でも, この人 は $95 \%$ ガンであると思うのではなかろうか.

ここには，情報の不完全性という問題がある．上記の情報は合理的判断をする上で不完全なの である，そこで，次の情報を追加しよう．

・このガンがないときでも＋になる確率は $5 \%$ ある.

・一般に, このガンは 10,000 人に一人見つかる(事前確率).

そこで, 検査で + となったという事象を $A$ ，このガンが存在するという事象を $B$ として計算 してみよう．計算すべきは事後確率 $P(B \mid A)$ である. また利用できるのは, $P(A \mid B)=0.95$, $P(A \mid \bar{B})=0.05, P(B)=0.0001$ である. ベイズの公式により

$$
P(B \mid A)=\frac{P(A \mid B) P(B)}{P(A \mid B) P(B)+P(A \mid \bar{B}) P(\bar{B})} \cong 0.002 .
$$

このように, 検査が + になった後でも, このガンが存在する確率は $1 / 500$ に過ぎない.

一般の人々がベイズの公式をあやつることは不可能に近いかも知れないが，次のように，ごく 簡単に言い換えることができる.

「一万人のなかにこのガンの人が一人いる．これらの人がすべてこの検査を受けたとする．一人 いるガンの人が + となるのはほぼ確実で, これを 1 名とカウントする. 残りの 9,999名のなかで, 誤って + と判定される人は約 500 名いる. よって, ある人について +の結果が出たとき, この 人はガンである 1 名かガンでない 500 名のいずれかである.」

上記のように説明すれば，ベイズの定理に言及する必要はない．このような説明の工夫は，リ スクコミュニケーションで必要なことと思われる．また，不完全な情報が与えられたとき，それ をいかに完全化するかは重要な問題であろう.

\section{6. 逆 問 題}

工学の諸分野では, 与えられた条件のもとで方程式の解を計算する問題や, 最適解を求める問 題が通常の問題(順問題)であるが，それに劣らず，逆問題の考察が重要である．与えられた結果 を出力するようなシステムへの入力やパラメータを求める事が逆問題の一例である.

さらに広い意味で逆問題を捉えると，与えられた入出力関係を満たすシステムモデルを選択す るモデル選択問題や, 解けるような形に定式化を行う際の必要な情報を得ることも重要と思われ る.この意味では, 先に挙げたような不完全情報を完全化するにはどうすれば良いか, なども広 義の逆問題であろう. なお, 中西 (2004) はリスク発見の問題一般を広義の逆問題として捉えるこ との重要性について述べている. 
人工知能分野では, 多量のデー夕集合から分類規則を抽出する問題が, 多く取り上げられてい て，知識発見あるいはデータマイニングと呼ばれている．また，データマイニングを扱う分野を 独立させて, 発見科学ということもある. 通常の推論処理を順問題とすれば, データマイニング は逆問題の位置づけにあたる.

統計解析における典型的な逆問題の提唱は, Tukey (1977) による探索的デー夕解析 (exploratory data analysis)であり，仮説発見や，統計モデルに対する仮定の評価などが行われる．また，ベイ ズ統計学自体が, 結果から原因を推論するという逆問題の観点を有している.

意思決定の基礎理論である最適化に関連した逆問題はどうだろうか. 通常の最適化では，与え られた制約条件のもとでの最適化がはかられる。もし，いくつかの制約条件が互いに矛盾しあつ て, 最適化以前に, 制約条件をすべて満足する解がないならば, 問題は実行不可能 (infeasible) と 呼ばれる．ここで，オペレーショナル・リスクの例を思い出そう. 自己資本比率に対する制約条 件は, 実行可能性を要求しているが, 組織に立ち返ってみれば, 実行可能解があるような, シス テム諸条件の見直しが要求されていることになる.ここでは, 広義の逆問題が提起されていると みることができる.

また，意思決定において，最適化の代わりに，複数の目的や制約を満足化 (satisfice)するという アプローチが提唱されている. 満足化にあたつても, 目的達成度合いに関する適切なレべルを設 定して, 問題を実行可能とする必要があり, 逆問題が生じてくる. 後に, ファジィ集合を用いた 満足化の方法について述べるが, そこでは,「ソフトな満足化」の概念を用いて, 逆問題と順問題 の中間的な定式化が行われている.

\section{7. 確率以外のリスク記述モデル}

リスクを定量化するにあたっては, 確率・統計モデルが殆ど唯一の手段であるようにみられてい る. 確かに, 確率・統計モデルが最も信頼すべき方法論であることは疑いようがないが, 他の手 段が絶無というわけではない。この節では，不確実性を記述する他のモデルについて概観しよう.

\section{1 ファジィ集合論}

ファジィ集合論 (Zadeh (1965)) は, 今日よく知られた理論体系であり, 不確実性を確率論とは 異なる方法で表現している.

全体集合を $X$ とするとき， $X$ のファジィ集合 $A$ は単位区間 $[0,1]$ に值をとるメンバーシップ関 数 $\mu_{A}(x)$ によって特徵付けられる. メンバーシップ関数は, 通常の集合の特性関数 $f_{A}(x)$ の一般 化であり, 次のように意味付けられる.

1. $\mu_{A}(x)=1$ のとき, $x$ は $A$ に完全に所属している.

2. $\mu_{A}(x)=0$ のとき, $x$ は $A$ に全く所属していない.

3. $0<\mu_{A}(x)<1$ のとき, $x$ の $A$ への所属性はあいまいである.

4. $\mu_{A}\left(x^{\prime}\right)<\mu_{A}(x)$ のとき, $x$ の $A$ に対する所属性は $x^{\prime}$ のそれよりも大きい.

また，ファジィ集合 $A, B$ に対し，基本的関係と演算が次のように定義されている.

1. すべての $x \in X$ について $\mu_{A}(x) \leq \mu_{B}(x)$ のとき, $A \subseteq B$ と定義する.

2. すべての $x \in X$ について $\mu_{A}(x)=\mu_{B}(x)$ のとき, $A=B$ と定義する. 
3. $\mu_{A \cup B}(x)=\max \left\{\mu_{A}(x), \mu_{B}(x)\right\}$.

4. $\mu_{A \cap B}(x)=\min \left\{\mu_{A}(x), \mu_{B}(x)\right\}$.

$\mu_{A}(x)$ が 0 または 1 の值のみをとるとき, 明らかに, メンバーシップ関数は特性関数を表し，上 記の関係と演算は通常の集合におけるそれらに一致するから，ファジィ集合は通常の集合の一般 化に相当している．このように，ファジィ集合は，単位区間 $[0,1]$ に值をとる関数のラベルに，通 常の集合の一般化となるような集合演算ができるようにしたものである.

Bellman and Zadeh (1970) によるファジィ意思決定の定式化を述べよう.この方法は満足化の 概念に対応している. $X$ が決定変数のとる值の空間であるとする. 最適化にもとづく意思決定で は， $x$ を変数とする目的関数を制約条件のもとで最小化あるいは最大化するが，ファジィ意思決 定では，目的を満足する決定変数のファジィ集合を $D$ で表す．従って， $\mu_{D}(x)=1$ ならば，目的 は完全に満足され， $\mu_{D}(x)$ が小さくなるほど，満足の度合いは低くなる.いくつかの制約条件も ファジィ集合 $C_{1}, \ldots, C_{K}$ で表される. $\mu_{C_{i}}(x)=1$ ならば制約 $C_{i}$ は完全に満足される.このよう に制約についても，満足度の度合いを設定し，制約が満足されるかされないかのどちらかだけを 考えるのではなく，ソフトな制約を考えているところにこの定式化の特徵がある．このとき，目 的満足化は

$$
\max _{x} \mu_{D \cap C_{1} \cup \cdots \cap C_{K}}(x)=\max _{x} \min \left\{\mu_{D}(x), \mu_{C_{1}}(x), \ldots, \mu_{C_{K}}(x)\right\}
$$

によって定式化される. もし $\mu_{D}(x)=\mu_{C_{1}}(x)=\cdots=\mu_{C_{K}}(x)=1$ と目的と制約のすべてを満た す $x$ があるならば, この $x$ が上記の最適化の解となる.

このように最終的には最適化問題としての定式化がなされるが，その概念は，ファジィな満足 化であることに注意しなければならない。 また，目的と制約条件が区別されていない点は，多目 的最適化の概念とも関連している.

\section{2 可能性理論}

確率論とは別の不確実性を表現するための理論として Zadeh (1978) は可能性理論 (possibility theory）を提唱した. 可能性理論は非加法的な単調測度の一種である. 簡単のため, 全体集合 $X$

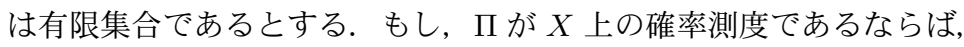

(i) $\Pi(\emptyset)=0, \Pi(X)=1$ ，と (ii) $A \cap B=\emptyset$ ならば $\Pi(A \cup B)=\Pi(A)+\Pi(B)$ が成り立つ。単調測度の場合は, 加法性 (ii)の代わりに, より弱い単調性

(ii'） $A \subseteq B$ ならば $\Pi(A) \leq \Pi(B)$

を仮定する．プロスペクト理論における $\pi(p(A))$ をこの測度とすれば, 非加法的単調測度となる ことに注意しょう.

単調測度の中で,

$$
\Pi(A \cup B)=\max \{\Pi(A), \Pi(B)\}
$$

を満たす測度を可能性測度といい, これと対になる測度として

$$
N(A \cap B)=\min \{N(A), N(B)\}
$$

を満たす測度を必然性測度という(Zadeh (1978), Dubois and Prade (1988))。 $A, B$ が排反事象の 場合の確率の性質 $P(A \cup B)=P(A)+P(B)$ と可能性測度の性質は対照的であり，また必然性測 Jpn J Biomet Vol. 29, Special Issue 2, 2008 
度と, 独立事象に対する $P(A \cap B)=P(A) P(B)$ も対照的である.

可能性・必然性測度が, 現在まで確率論に比肩できるような形で有用性を発揮したことはない. しかしながら, 可能性理論は, 後述の様相論理 (Chellas (1980)) とも深い関連性をもつことが示さ れている (Miyamoto et al. (2006)).

さらに, 非加法性の導入によって, プロスペクト理論で述べた, 小さい確率は大きく評価され る, という面も見逃せない. 微小な確率は, その值の評価自身に不確定性があり, かつ, 通常仮 定される事象の独立性についても，その仮定が妥当であるかどうかはあいまいである．このよう な場合も, 可能性・必然性の議論を取り入れる余地はあるのではないだろうか.

\section{3 様相論理}

記号論理と推論システムは人工知能の基礎理論であり, 最も簡単な命題論理では, 文 $A, B, C, \ldots$ と論理記号 $\neg A(A$ でない $), A \vee B(A$ または $B), A \wedge B(A$ および $B), A \rightarrow B(A$ ならば $B)$ を用いて, 文の論理関係を記述する. 様相論理では, これに加えて, $\square A$ ( $A$ は必然), $\diamond A$ ( $A$ は 可能)の様相記号が用いられる.

様相記号によって, どのように不確実性が表されるかは, 可能性世界モデル $<W, R, P>$ (Chellas (1980))によって示される. $W$ は可能世界の集合であり， $R$ はある世界から別の世界 へ到達できるか否かを示す $W$ 上の 2 項関係である. $P$ は原子文 (基礎となるそれ以上分解されな

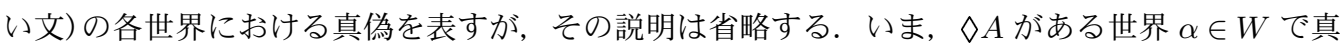
であるとは，Aが $R$ によって $\alpha$ から到達できる世界のどこかで真であることを意味する．この 際， $A$ は $\alpha$ 自体では真でなくてもよい. このように，ある事象の生起可能性が様相記号によって 記述される.

様相論理自体は，リスクを意味する不確実性を定性的に示すものであるが，可能世界モデルに おいてある文が真である世界の数をカウントするなど, 量的な指標を導入することは可能である. このようにすれば，確率論や証拠理論 (Shafer (1976)) との関連性が出てくる. また，様相論理を データマイニングに応用するための体系とみられるラフ集合論 (Pawlak (1982), Pawlak (1991)) では, 実際に量的指標が用いられている. 一方, 関係 $R$ にパラメー夕を導入して多様相を表現 することも可能であり，一種の多様相論理 (multimodal logic)を利用して，可能性理論を表現す ることもできる (Miyamoto et al. (2006))．さらには，意思決定のための論理も研究されている (赤間・宮本 (2007))，このように，様相論理は不確実性と意思決定と表現する論理的体系であり， 基礎理論として, 今後の研究の余地が多いと思われる.

\section{8. リスク・リテラシー}

近年, リテラシー (literacy, 読み書き能力, 基礎的素養)という言葉がコンピュータ・リテラ シー，メディア・リテラシーという使い方とともに市民権を得るようになってきており，それとと もに最近，リスク・リテラシーという用語も耳にするようになってきた (林 (2005), 竹内他 (2005), 宮本 (2006))。一方で, 欧米でもリスク・リテラシーという言い方は存在するが, それほど一般 的ではないようである(宮本 $(2006)$ ).

林 (2005) の著書は, リスク・リテラシーを扱っており, その内容は様々なリスク・災害・事故 
とそれらへの対応の事例集である.リスクという用語と現実に生起した事象との区別があいまい であるなど定義に関する問題はあるが，ビジネスにおけるリスク管理に役立つ内容が指向されて いる. また，竹内他 (2005) では, 「水害リスクリテラシー」という言い方がされており，水害に 関わるリスクコミュニケーションを行う上での基礎的知識，という意味で用いられている.

リスク管理におけるコミュニケーションの重要性は今日広く認識されており, リスクコミュニ ケーションと呼ばれる研究領域を形成しているが, リスク・リテラシーもリスクコミュニケーショ ンの中に位置づけられると思われる(宮本 (2006))。 また, リスク・リテラシーと称してはいない が, 広く一般読者にリスク認識の必要性を訴えているという意味で, 先に述べた中谷内 $(2006)$ も 一種のリスク・リテラシーを意図しているとも解釈できるであろうし，中西が「リスクの読み書 き」（中西 (2004)）と述べている事柄はリスク・リテラシーと呼ぶにふさわしい，また，リスク・ リテラシーの議論には, リスクを定性的に捉えている場合と, 定量的に捉えている場合の両方が あるが，中谷内が述べているように，必ずしも専門家ではなくとも，リスクは定量的に捉えるべ きであり, 定量化を含むリスク・リテラシーが必要と思われる.

リスクと関連する概念であるセキュリティ, 特に情報セキュリティについては, セキュリティ・ リテラシーという使い方がなされている．情報セキュリティはコンピュータの管理に関わる限定 された概念であり, 情報セキュリティ・リテラシーという用語については, コンピュータリテラ シーの範疇で論じることができる，このように，情報セキュリティ・リテラシーに関する概念上 の問題はないと思われるが, より広義のセキュリティ・リテラシーについても今後議論が盛んに なると考えられる．そのような場合，リスク・リテラシーとセキュリティ・リテラシーとの関連 性や区別の議論も必要となるであろう.

\section{9.おわりに}

リスク管理に関する基本的概念について概観すると同時に，定量化に関わるいくつかのアプロー チをみてきた，そこで，以下のようなことを確認することができよう.

1. リスク定量化に関わる基本的測度は, 確率と費用であり, これらの組み合わせによって, 異なるリスクの比較が可能となる (中西 (2004))．いくつか異なるリスクが存在する場合, そ れらを比較して, 最適な意思決定を行うことが必要となり, それには最適化の概念が関わつ てくる．投資の分野に限っていえば，ポートフォリオ理論はその典型である.

2. リスク評価に関わる問題には広義の逆問題が多い. 逆問題へのアプローチは様々であるが, 統計科学と情報科学 (発見科学) を融合させた方法論が期待される.

3. 定量的リスク評価は, 広く一般に受け入れられるべきであり，その意味で，リスク・リテ ラシーは重要となってくる，そのためには，情報の不完全さを認識し，完全化をはかるべき であろう。

ここでは述べなかつたが, 冒頭に述べた安全・安心という標語について, 山岸(山岸 $(2001)$, 山岸 (1999)) は, 我が国は安心社会から信頼社会へと移行すべきであると述べており, 傾聴に值 する. また, リスクの定量化 (モノサシ)について, 中谷内 (2006) は武田 (2006) による様々なリ スク評価基準を集めた web ページを参照している，さらに，リスク下の意思決定に関して，歴史 
的に広範な議論が行われている本として Bernstein (1996) がある. 邦訳も出ており, 一読の価值 がある.

\section{参 考 文 献}

赤間世紀, 宮本定明 (2007). ソフトコンピューティングのロジック, 工学社.

甘利康文 (2004). セキュリティの基本的考え方とリスクマネジメントとの関係について, 信学技 報, Vol. 104, No. 528 .

J. R. Anderson (1985). Cognitive Psychology and Its Applications, 2nd Ed., Freeman.

J. Ansell and F. Wharton, eds. (1992). Risk: Analysis, Assessment and Management, Wiley.

T. Bedford and R. Cooke (2001). Probabilistic Risk Analysis: Foundations and Methods, Cambridge Univ. Press. (邦訳：金野秀敏訳, 確率論的リスク解析, シュプリンガー・ジャパン, 2006).

R. Bellman and L. A. Zadeh (1970). Decision-making in a fuzzy environment, Management Science, Vol.17, No. 4, pp. 141-164.

P. L. Bernstein (1996). Against the Gods, Wiley. (邦訳：青山護訳, リスク, 神々への反逆, 日本経 済新聞社, 2001)

B. F. Chellas (1980). Modal Logic: An Introduction, Cambridge Univ. Press.

D. Dubois and H. Prade (1988). Possibility Theory, Plenum.

林 志行 (2005). 事例で学ぶリスクリテラシー入門, 日経 BP 社.

D. Kahneman and A. Tversky (1979). Prospect Theory: An Analysis of Decision Under Risk, Econometrica, Vol. 47, No. 2, pp. 263-291.

D. Kahneman, P. Slovic and A. Tversky (1982). Judgment Under Uncertainty: Heuristics and Biases, Cambridge Univ. Press.

甲斐良隆 (2002). 資産運用とリスクマネジメント, エコノミスト社.

鎌倉治子 (2003). 新 BIS 規制とオペレーショナルリスク：銀行の自己資本比率に関する国際的な 規制・監督の動向, レファレンス, 2003 年 9 月号, pp. 55-67.

D.M. Kammen and D.M. Hassenzahl (1999). Should We Risk It? Exploring Environmental, Health, and Technological Problem Solving, Prinston Univ. Press.

刈屋武昭 (1990). ポートフォリオ計量分析の基礎, 東洋経済新報社.

F. H. Knight (2006). Risk, Uncertainty, and Profit, Dover, (originally published 1921).

今野 浩 (1995). 理財工学 I, 日科技連.

S. Miyamoto, T. Murai and Y. Kudo (2006). A Family of Polymodal Systems and its Application to Generalized Possibility Measures and Multi-Rough Sets, Journal of Advanced Computational Intelligence and Intelligent Informatics, Vol. 10, No. 5, pp. 625-632. 
宮本定明編 (2006). 平成 18 年度大学教育の国際化推進プログラム (海外先進教育実践支援)『リス ク管理共通教育中核教員団の養成』報告書.

http://soft.risk.tsukuba.ac.jp/miyamoto/risk/indexRiskManagementReport.html 中西準子 (2004). 環境リスク学, 日本評論社.

中谷内 一也 (2006). リスクのモノサシ：安全・安心生活はありうるか, 日本放送出版協会. 岡本浩一 (1992). リスク心理学入門, サイエンス社.

Z. Pawlak (1982). Rough sets, International Journal of Computer and Information Sciences, Vol. 11, pp. 341-356.

Z. Pawlak (1991). Rough Sets, Kluwer Academic Publishers, Dordrecht.

G. Shafer (1976). A Mathematical Theory of Evidence, Princeton Univ. Press.

P. Slovic (1987). Perception of Risk, Science, Vol. 236, pp. 280-285, 17 April.

武田篤彦 (2006). リスクと生活, http://www.taishitsu.or.jp/risk/risk2006.html

竹内, 高尾, 下川, 佐藤, 副直, 池田 (2005). 水害リスクリテラシー学習支援ツールの検証, 防災科 学技術研究所研究報告, Vol. 67, pp.63-71.

J. W. Tukey (1977). Exploratory Data Analysis, Addison-Wesley.

F. Wharton (1992). Risk Management: Basic Concepts and General Principles, in J. Ansell, F.

Wharton, eds., Risk: Analysis, Assessment and Management, Wiley, Chapter 1, pp.1-14.

山岸俊男 (2001). 安全社会と信頼社会, WEB OJO 2001.11

http://adv.yomiuri.co.jp/ojo/02number/200111/11toku.html WEB OJO Vol.4, No.8, 2001.11

山岸俊男 (1999). 安心社会から信頼社会へ一日本型システムの行方, 中公新書.

L. A. Zadeh (1965). Fuzzy sets, Information and Control, Vol. 8, No. 3, pp. 338-353.

L. A. Zadeh (1978). Fuzzy sets as a basis for a theory of possibility, Fuzzy sets and Systems, Vol. 1, pp. 3-28. 